\title{
Effect of Semen Diluents, Dilution Rates, and Storage Periods on Spermatozoa Motility of Different Varieties of Guinea Fowl
}

\section{Keerthy AJ1, Omprakash AV $^{2}$, Churchil RR ${ }^{3}$ and Hudson $\mathbf{G H}^{4 *}$}

${ }^{1}$ Directorate of Animal Husbandry, Kerala, India

${ }^{2}$ Poultry Research Station, Madhavaram Milk Colony, Chennai, Tamil Nadu, India

${ }^{3}$ Institutional Livestock Farm Complex, Veterinary College and Research Institute, Orathanadu, Thanjavur, Tamil Nadu, India

${ }^{4}$ Department of Poultry Science, Madras Veterinary College, Chennai, Tamil Nadu, India

\begin{abstract}
Twelve number of healthy male guinea fowls from each variety of pearl, white, white breasted and lavender were selected based on the phenotypoic characters and trained for semen collection by abdominal massage technique. Pooled semen from each variety, were diluted with the Lakes Semen Extender, Modified Beltsville Poultry Semen Extender, and Beltsville Poultry Semen Extender each in the ratio of 1:3, 1:4 and 1:5. The spermatozoa motility was assessed at 0,1, 2, 4 and 6 hours of storage. Maximum per cent motility of 83.33, 86.67 and 79.19 were observed in the semen of pearl, white breasted and lavender varieties of guinea fowl diluted Beltsville Poultry Semen Extender in the ration 1:4 at $6 \mathrm{~h}$ of storage. Maximum spermatozoa motility with white guinea fowl variety at maximum storage period was observed with the semen diluted (1:3) with Beltsville Poultry Semen Extender (81.67\%). The current study will be of immense useful for the selection of semen diluents for better fertility through artificial insemination in guinea fowls.
\end{abstract}

Keywords: Spermatozoa motility; Guinea fowl; Fertility

\section{Introduction}

Guinea fowls are hardy, semi wild poultry that are yet to be genetically improved for commercial meat and egg production. The fertility in guinea fowls is low which forms the major constraint for its genetic improvement and commercial exploitation. In addition, sexing problems [1], seasonality of breeding [2-4], monogamous behavior [5] may also contribute to lower fertility rates. Artificial insemination is the novel tool for improving the fertility in domestic animals and poultry. The technology can be successful only with superior semen quality. Spermatozoa motility is the important parameter that determines the movement of spermatozoa in the female oviduct. It was reported that the number of progressively motile sperm per ejaculate was the most consistent and reliable trait correlated with fertility [6]. Positive correlations between spermatozoa motility and fertility have been reported by several authors in different species of poultry $[7,8]$. Poultry spermatozoa are fragile, and the semen quality of raw semen deteriorates within one hour of collection [9]. Although published reports regarding the seminology of guinea fowls are less, the advantages of using the semen diluents in other poultry species were reviewed. The semen diluents are reported to be used to extend semen, maintain the livability and fertilizing capacity in vitro, and maximize the number of hens that can be inseminated [10]. Therefore the efficiency of different semen diluents in maintaining the spermatozoa motility of different varieties of Guinea Fowl namely the pearl, white, white breasted and lavender, under short term storage was studied.

Three semen diluents namely the Lakes Semen Extender (LSE), Modified Beltsville Poultry Semen Extender (MBPSE) and Beltsville Poultry Semen Extender (BPSE) were used for the current study. The spermatozoa motility of raw semen of pearl, lavender and white varieties was reported as $87.00 \pm 4.40,90.11 \pm 3.70$ and $84.34 \pm 5.11$ respectively [11]. The superiority of BPSE over many othersemen diluents were also reported in different poultry species [12-14]. The decrease in spermatozoa motility with increase in the dilution ratio and storage periods were reported with BPSE and IMV diluents in the ratio 1:2 and 1:3 stored for up to six hours [13]. No works regarding MBPSE with guinea fowl semen could be traced. The current study was carried out during October- December months where the average daily high temperature in the study area $\left(13.1623^{\circ} \mathrm{N}, 80.2433^{\circ} \mathrm{E}\right)$ was was between $22 \mathrm{oC}$ and $31 \mathrm{oC}$. The birds used for the study were housed in individual cages and maintained under standard feeding and manage mental conditions.

\section{Materials and Methods}

Initially 12 healthy, mature male guinea fowls aged eight months were selected based on their phenotypic characters from each variety of guinea fowl namely the pearl, white, white breasted and lavender. They were housed in individual cages providing a floor space of 1 sq. $\mathrm{ft}$. per bird. Breeder ration containing $17 \%$ crude protein, $2700 \mathrm{kcal}$ of Metabolisable Energy, 3\% calcium, 1\% lysine and 0.50\% methionine was provided at ad libitum with free access to drinking water. The feathers around the vent region of the birds were clipped off and were trained for semen collection for a period of about one month.

Semen was collected during early hours of the day between twice a week following abdominal massage technique [14]. Pooled semen sample collected was then diluted with three different diluents namely the LSE [15], MBPSE [16] and BPSE [17]. The $\mathrm{pH}$ and osmolarity were measured and adjusted to standard levels using DALAL $\mathrm{pH}$ meter and OSMOMAT 030 cryoscopic osmometer respectively.

Exactly $100 \mu \mathrm{L}$ of raw semen was diluted with $200 \mu \mathrm{L}, 300 \mu \mathrm{L}$ and $400 \mu \mathrm{L}$ of each diluent in sterile eppendorf tubes to get the final dilution of 1:3, 1:4 and 1:5 respectively. The tubes were then stored at $5^{\circ} \mathrm{C}$ and the spermatozoa motility were analyzed at zero, one, two, four

${ }^{*}$ Corresponding author: Hudson GH, Department of Poultry Science, Madras Veterinary College, Chennai, Tamil Nadu, India, Tel: +91-994-437-2582 ; E-mail: hudson.bvsc@gmail.com

Received August 20, 2016; Accepted August 29, 2016; Published September 02, 2016

Citation: Keerthy AJ, Omprakash AV, Churchill RR, Hudson GH (2016) Effect of Semen Diluents, Dilution Rates, and Storage Periods on Spermatozoa Motility of Different Varieties of Guinea Fowl. J Vet Sci Technol 7: 378. doi: 10.4172/21577579.1000378

Copyright: (c) 2016 Keerthy AJ, et al. This is an open-access article distributed under the terms of the Creative Commons Attribution License, which permits unrestricted use, distribution, and reproduction in any medium, provided the original author and source are credited. 
Citation: Keerthy AJ, Omprakash AV, Churchill RR, Hudson GH (2016) Effect of Semen Diluents, Dilution Rates, and Storage Periods on Spermatozoa Motility of Different Varieties of Guinea Fowl. J Vet Sci Technol 7: 378. doi: 10.4172/2157-7579.1000378

Page 2 of 6

and six hours of storage. A drop of diluted semen with the aid of a micropipette was placed on a microscope slide, which was then covered with a glass cover slip and examined under $400 \mathrm{x}$ magnifications in a light microscope. The motility determination was carried out by taking into consideration subjective measurements based on the judgment of individuals making the determination. The motility was expressed as the percentage of cells that are motile under their own power [18].

The statistical analysis of the data was carried out by one way ANOVA using Statistical Package for the Social Sciences 20.0 software [19].

\section{Results}

Effect of different semen extenders, dilution ratio and storage periods on motility of pearl, white, white breated and lavender guinea fowl spermatozoa at $5^{\circ} \mathrm{C}($ Mean $\pm \mathrm{SE})$ were presented from Tables $1-4$ respectively.

\section{Pearl variety}

The duration of storage had a significant $(\mathrm{P} \leq 0.05)$ effect in semen diluted with LSE and MBPSE in 1:3 dilution rates with significant $(\mathrm{P} \leq 0.05)$ reduction after $4 \mathrm{~h}$ post-dilution. However there was no significant $(\mathrm{P} \geq 0.05)$ difference between storage periods in semen diluted with BPSE at 1:3 dilution rates. At 1:4 dilution rates, significant change in motility was observed in semen diluted with LSE $(\mathrm{P} \leq 0.01)$ and BPSE $(\mathrm{P} \leq 0.05)$ but not with MBPSE. The reduction of motility became significant $(\mathrm{P} \leq 0.05)$ at 2 and $4 \mathrm{~h}$ post-dilution in LSE and MBPSE respectively. In case of 1:5 dilution rates, significant $(\mathrm{P} \leq 0.01)$ reduction in motility was noticed only in semen diluted with LSE.

Irrespective of the dilution rates, there observed significant difference $(\mathrm{P} \leq 0.05)$ between the extenders at $6 \mathrm{~h}$ of storage with BPSE maintaining significantly $(\mathrm{P} \leq 0.05)$ higher motility compared to other two semen extenders. The different dilution rates with a particular semen extender at any particular storage period did not have any significant effect on motility.

\section{White variety}

The duration of storage had a significant effect in both semen

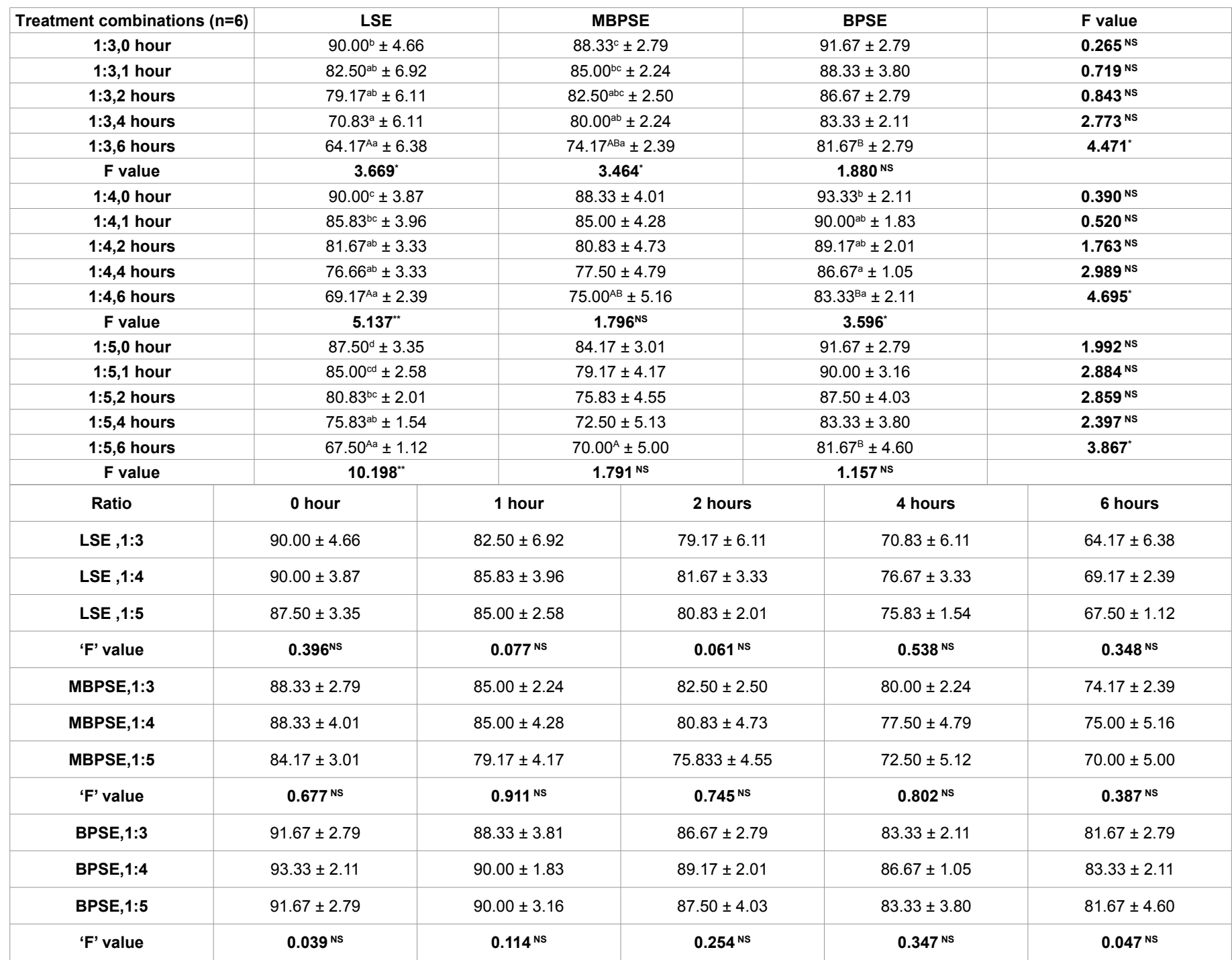

Means bearing different superscripts in uppercase letter in a row and lowercase letter in a column differ significantly. "*Highly significant $(P \leq 0.01),{ }^{*}$ Significant $(P \leq 0.05)$, NS. Not significant $(P>0.05)$.

Table 1: Effect of different semen extenders- dilution ratio and storage periods on motility of pearl guinea fowl spermatozoa at $5^{\circ} \mathrm{C}(\mathrm{Mean} \pm \mathrm{SE})$. 


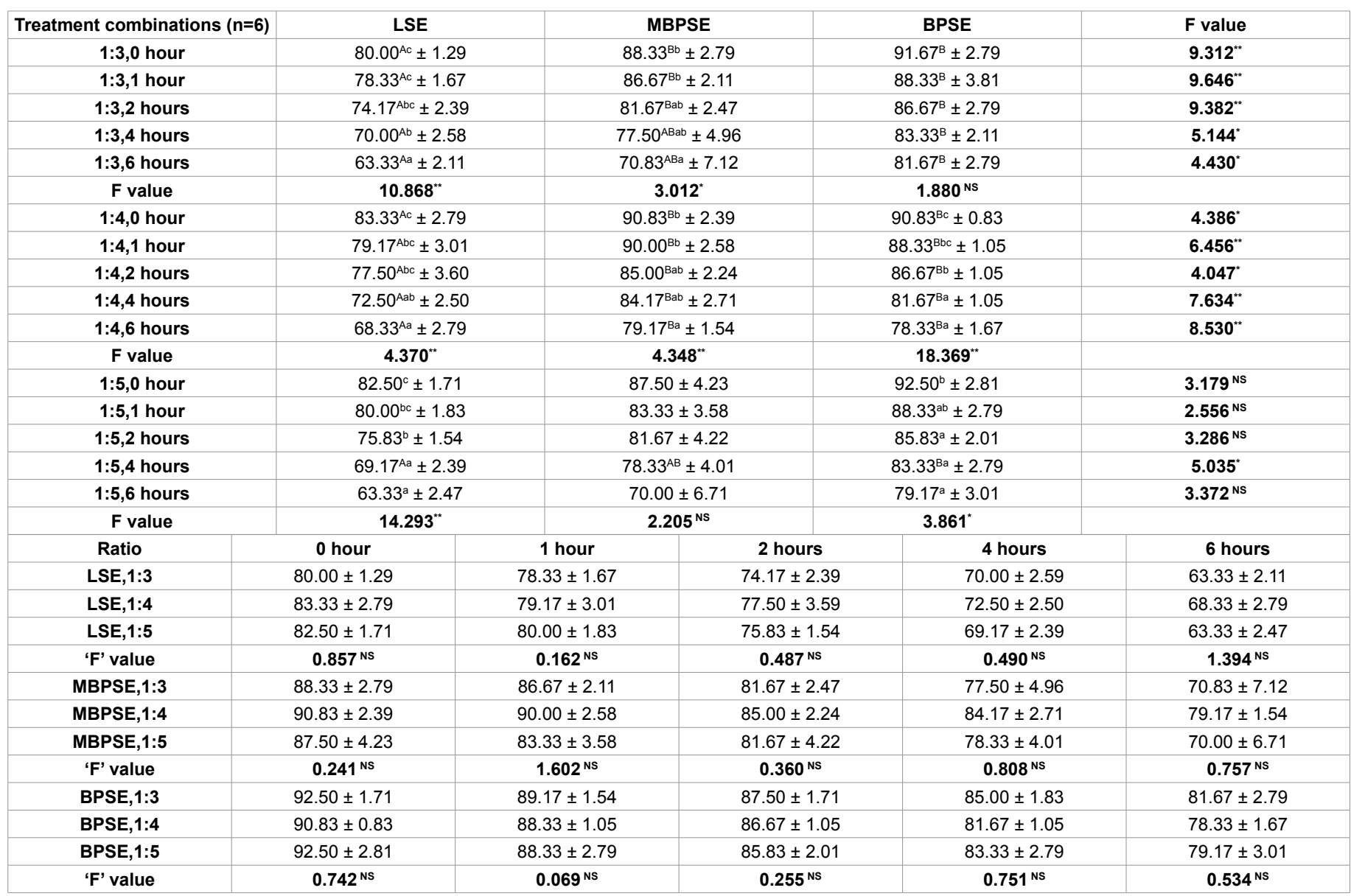

Means bearing different superscripts in uppercase letter in a row and lowercase letter in a column differ significantly, "*Highly significant $(P \leq 0.01)$, ${ }^{*}$ ignificant $(P \leq 0.05)$, Ns_Not significant $(P>0.05)$.

Table 2: Effect of different semen extenders - dilution ratio and storage periods on motility of white guinea fowl spermatozoa at $5^{\circ} \mathrm{C}$ (Mean $\pm \mathrm{SE}$ ).

diluted with LSE $(\mathrm{P} \leq 0.01)$ and MBPSE $(\mathrm{P} \leq 0.05)$ at $1: 3$ dilution rates. However there was no significant $(\mathrm{P}>0.05)$ difference in semen diluted with BPSE at 1:3 dilution rate. Significant $(\mathrm{P} \leq 0.01)$ reduction in motility observed in semen diluted with LSE, MBPSE and BPSE at 1:4 dilution rate from 0 to 6 hours of storage. The reduction in motility became evident $(\mathrm{P} \leq 0.05)$ at $4 \mathrm{~h}$ post-dilution in LSE and BPSE and 6 $\mathrm{h}$ post-dilution in MBPSE. At 1:5 dilution rate there was no significant reduction in motility in semen diluted with MBPSE, however there was significant reduction in motility in semen diluted with LSE $(\mathrm{P} \leq 0.01)$ and BPSE $(\mathrm{P} \leq 0.05)$. Further semen diluted with BPSE at $1: 3$ and BPSE and MBPSE at 1:4 dilution rate maintained higher motility at 6 $\mathrm{h}$ storage period.

The superiority of BPSE over other diluents was much evident with 1:3 and 1:4 dilutions, irrespective of the storage periods. Whereas, with 1:5 dilution, significant difference in spermatozoa motility, was observed only at 4 hours of storage. The dilution rate alone did not show any significant difference between storage periods for each semen extender.

\section{White breasted}

The duration of storage had a significant $(\mathrm{P} \leq 0.05)$ effect on the spermatozoa motility of the white breasted Guinea Fowl semen diluted with LSE at 1:3 dilution rate and MBPSE at 1:3 and 1:5 dilution rates with reduction in motility from $0 \mathrm{~h}$ to $6 \mathrm{~h}$ of storage. With respect to BPSE, highly significant $(\mathrm{P} \leq 0.01)$ reduction in motility was observed from from $0 \mathrm{~h}$ to $6 \mathrm{~h}$ of storage in all the dilution rates under study. Further, irrespective of dilution rates, the semen diluted with BPSE had maintained superior spermatozoa motility at $6 \mathrm{~h}$ of storage compared to LSE and MBPSE diluents.Lavender

The duration of storage had high significant $(\mathrm{P} \leq 0.01)$ effect in all other combinations except for LSE in 1:3 dilution rates. Further BPSE has maintained higher motility at $6 \mathrm{~h}$ storage period at all dilution rates compare to other semen extenders. There was significant difference observed in motility for semen diluted with LSE, MBPSE and BPSE except for $1: 4$ at $4 \mathrm{~h}$ of storage period. The dilution rate alone showed significant $(\mathrm{P} \leq 0.05)$ difference in semen diluted with MBPSE at 0 and $6 \mathrm{~h}$ and BPSE at 1 and $2 \mathrm{~h}$. The dilution rate alone showed highly significant $(\mathrm{P} \leq 0.01)$ difference for MBPSE at $1 \mathrm{~h}$ and BPSE at $0 \mathrm{~h}$ of storage period. LSE was not influenced by dilution rate for different storage periods. After dilution, the motility was progressively reduced in all semen extenders and the reduction was significant $(\mathrm{P} \leq 0.05)$ at 2 and $6 \mathrm{~h}$ post-dilution in $1: 4$ and 1:5 ratios with LSE, at 2, 4 and $6 \mathrm{~h}$ in all dilutions (1:3, 1:4 and 1:5). The addition MBPSE at 1:3 ratios has resulted in time-related reduction in spermatozoa motility at time intervals of post-dilution, 1 and $4 \mathrm{~h}$ at 1:4 ratio and 2 and $4 \mathrm{~h}$ at 1:5 dilution rates.

\section{Discussion}

Based on the dilution studies it was interpreted that among the diluents, the BPSE has shown its superiority over other diluents 


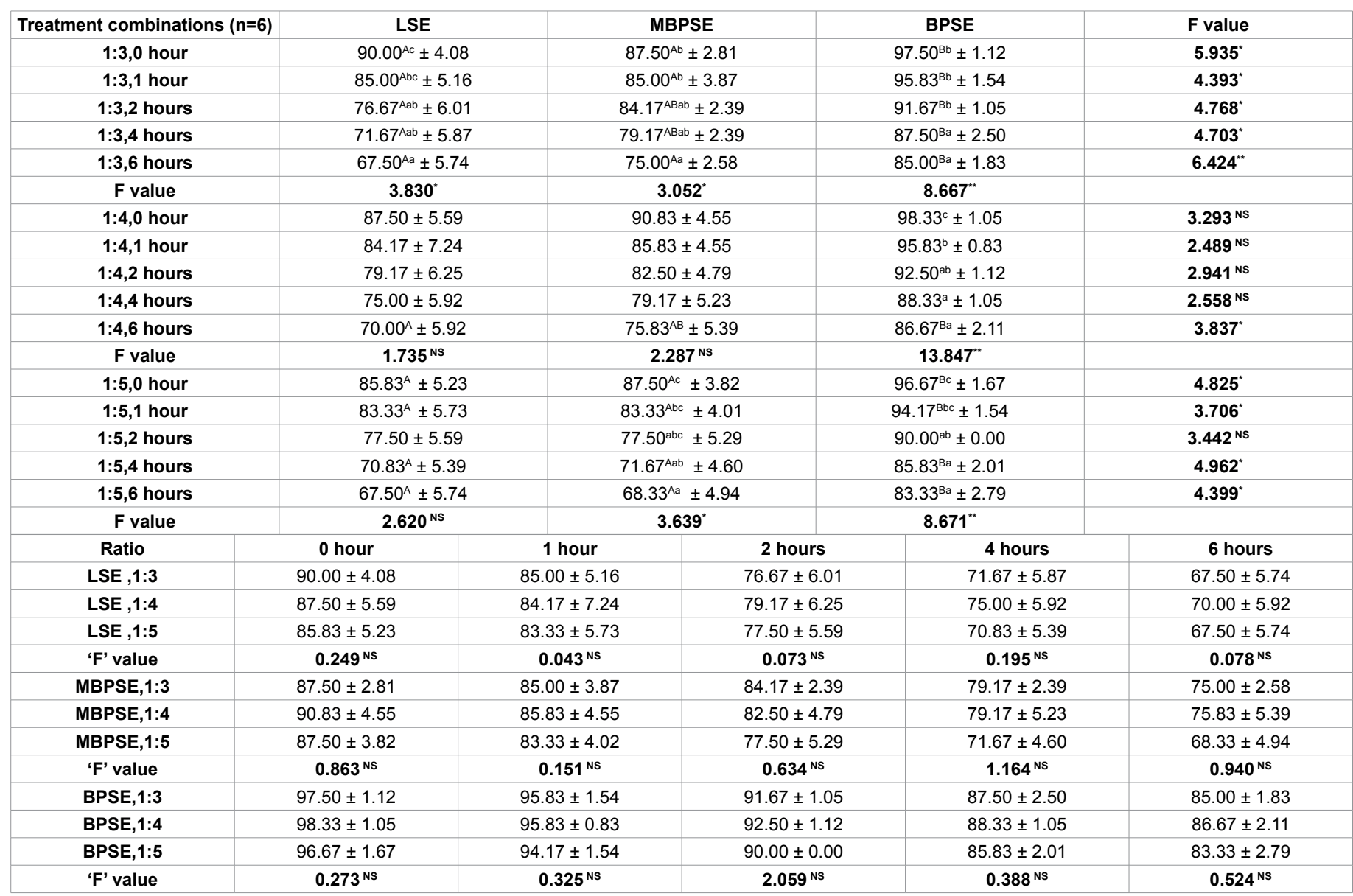

Means bearing different superscripts in uppercase letter in a row and lowercase letter in a column differ significantly, ${ }^{* *}$ Highly significant $(\mathrm{P} \leq 0.01),{ }^{*}$ Significant $(\mathrm{P} \leq 0.05)$, NS. Not significant $(P>0.05)$.

Table 3: Effect of different semen extenders-dilution ratio and storage periods on motility of white breasted guinea fowl spermatozoa at $5^{\circ} \mathrm{C}(\mathrm{Mean} \pm \mathrm{SE}$ )

in maintaining the motility of guinea fowl different varieties of spermatozoa under short term storage. The results obtained were in agreement with the previous studies in turkey semen [8,12]. In addition, higher fertility percentage were reported in turkey semen diluted with BPSE extender stored for 24 hours [14] which may also be attributed to superior motility compared to IMV and MTGA diluents. However, the superiority of CARI diluent over BPSE, LSE and normal saline for a 24 hour storage period were also interpreted with higher fertility rates in guinea fowls [20]. The varying values obtained between the extenders may be due to different $\mathrm{pH}$, composition of the diluents, metabolites released upon storage etc.

Irrespective of the diluents and dilution rates, the spermatozoa motility showed a declining trend, as storage time progresses from 0-6 hours. Similar results were also reported in Helmeted guinea fowl semen preserved in powdered coconut water [21] and turkey semen diluted (1:2) with poultry semen extender [22]. Complementary results were also obtained in guinea fowl semen in CARI $(24 \mathrm{~h})$, BPSE (6 h) and IMV $(6 \mathrm{~h})$ diluents in guinea fowl semen $[13,23]$. The reduction in motility may be attributed to the release of sperm metabolites which alter the nutrient composition of the medium. Further, storage alters the osmolarity [24] of the medium, which leads to various sperm abnormality, which further reduces the progressive motility. It was reported that storage of fowl semen in ringer's solution causes increased production of chloride ions which increases the spermatozoa abnormality [25]. The similar ionic changes that affect spermatozoa motility in guinea fowl semen needs to be further investigated with specific diluents under consideration. Identification of these attributes in future, may lead to efficient long term liquid storage of guinea fowl semen.

The dilution rate did not showed any significant difference between storage periods irrespective of the extenders and the guinea fowl varieties. However, the superior per spermatozoa motility at lower dilution (1:2 and 1:3) were reported with BPSE and IMV diluents [13]. The non-significant effects of dilution rates may be due to higher dilution rates used in the current study.

\section{Conclusion}

The dilution studies revealed that, the semen diluted with BPSE (1:4) and MBPSE (1:4) or BPSE (1:3) in pearl and white variety of guinea fowls respectively, and BPSE (1:4) in white breasted and lavender varieties, stored for $6 \mathrm{~h}$ is recommended, as the above combinations maintained superior motility, which may further yield better fertility through artificial insemination in Guinea Fowls.

\section{Acknowledgements}

The authors are highly thankful to Dean, Madras Veterinary College, Chennai and Hon'ble Vice Chancellor, Tamil Nadu Veterinary and Animal Sciences University for providing all the necessary support and facilities for conducting this study. 
Citation: Keerthy AJ, Omprakash AV, Churchill RR, Hudson GH (2016) Effect of Semen Diluents, Dilution Rates, and Storage Periods on Spermatozoa Motility of Different Varieties of Guinea Fowl. J Vet Sci Technol 7: 378. doi: 10.4172/2157-7579.1000378

Page 5 of 6

\begin{tabular}{|c|c|c|c|c|c|}
\hline Treatment combinations $(n=6)$ & LSE & \multicolumn{2}{|c|}{ MBPSE } & BPSE & F value \\
\hline 1:3,0 hour & $82.50^{A} \pm 2.81$ & \multicolumn{2}{|c|}{$85.83^{\mathrm{ABd}} \pm 2.01$} & $90.83^{\mathrm{Be}} \pm 0.83$ & $4.751^{*}$ \\
\hline 1:3,1 hour & $78.33^{\mathrm{A}} \pm 2.79$ & \multicolumn{2}{|c|}{$83.33^{\mathrm{Ad}} \pm 1.05$} & $88.33^{\mathrm{Bd}} \pm 1.05$ & $9.026^{* *}$ \\
\hline $1: 3,2$ hours & $76.67^{A} \pm 3.58$ & \multicolumn{2}{|c|}{$78.33^{\mathrm{Ac}} \pm 1.67$} & $85.00^{\mathrm{BC}} \pm 0.00$ & $4.453^{*}$ \\
\hline $1: 3,4$ hours & $74.17^{A} \pm 3.96$ & \multicolumn{2}{|c|}{$73.33^{\mathrm{Ab}} \pm 1.67$} & $81.67^{\mathrm{Bb}} \pm 1.05$ & $3.752^{*}$ \\
\hline 1:3,6 hours & $70.00^{A} \pm 4.08$ & \multicolumn{2}{|c|}{$61.67^{\mathrm{Aa}} \pm 1.67$} & $76.67^{\mathrm{Ba}} \pm 1.05$ & $8.782^{* *}$ \\
\hline F value & $2.041^{\mathrm{NS}}$ & \multicolumn{2}{|c|}{$31.176^{* *}$} & $34.855^{* *}$ & \\
\hline 1:4,0 hour & $86.67^{\mathrm{AC}} \pm 1.67$ & & & $93.33^{\mathrm{Bc}} \pm 1.05$ & $8.585^{* *}$ \\
\hline 1:4,1 hour & $81.67^{\mathrm{Abc}} \pm 1.67$ & & & $90.00^{\mathrm{cb}} \pm 0.00$ & $24.222^{* *}$ \\
\hline 1:4,2 hours & $79.17^{\mathrm{Ab}} \pm 2.39$ & & & $87.50^{\mathrm{Bb}} \pm 1.12$ & $8.227^{* *}$ \\
\hline 1:4,4 hours & $75.00^{\mathrm{ab}} \pm 2.58$ & & & $82.50^{\mathrm{a}} \pm 1.71$ & $2.511^{\mathrm{NS}}$ \\
\hline 1:4,6 hours & $70.00^{\mathrm{Aa}} \pm 2.58$ & & & $79.17^{\mathrm{Ba}} \pm 2.01$ & $4.447^{\star}$ \\
\hline F value & $8.832^{* *}$ & & & $18.861^{* *}$ & \\
\hline 1:5,0 hour & $85.83^{\mathrm{BC}} \pm 0.83$ & & & $88.33^{\mathrm{BC}} \pm 1.05$ & $8.291^{* *}$ \\
\hline 1:5,1 hour & $80.83^{\mathrm{Ab}} \pm 0.83$ & & & $86.67^{\mathrm{Bbc}} \pm 1.05$ & $12.940^{* *}$ \\
\hline 1:5,2 hours & $79.17^{\mathrm{Ab}} \pm 0.83$ & & & $84.17^{\mathrm{Bb}} \pm 0.83$ & $13.058^{* *}$ \\
\hline 1:5,4 hours & $73.33^{\mathrm{Aa}} \pm 1.67$ & & & $80.83^{\mathrm{Ba}} \pm 0.83$ & $13.769^{* *}$ \\
\hline 1:5,6 hours & $70.83^{A a} \pm 2.39$ & & & $78.33^{\mathrm{Ba}} \pm 1.05$ & $13.283^{* *}$ \\
\hline F value & $18.195^{* *}$ & & & $17.199^{* *}$ & \\
\hline Ratio & 0 hour & 1 hour & 2 hours & 4 hours & 6 hours \\
\hline LSE,1:3 & $82.50 \pm 2.81$ & $78.33 \pm 2.79$ & $76.67 \pm 3.58$ & $74.17 \pm 3.96$ & $70.00 \pm 4.08$ \\
\hline LSE,1:4 & $86.67 \pm 1.67$ & $81.67 \pm 1.67$ & $79.17 \pm 2.39$ & $75.00 \pm 2.58$ & $70.00 \pm 2.58$ \\
\hline LSE,1:5 & $85.83 \pm 0.83$ & $80.83 \pm 0.83$ & $79.17 \pm 0.83$ & $73.33 \pm 1.67$ & $70.83 \pm 2.39$ \\
\hline 'F' value & $1.244^{\mathrm{NS}}$ & $0.794^{\mathrm{NS}}$ & $0.288^{\mathrm{NS}}$ & $0.104^{\mathrm{NS}}$ & $0.022^{\mathrm{NS}}$ \\
\hline MBPSE,1:3 & $85.83^{\mathrm{ab}} \pm 2.01$ & $83.33^{b} \pm 1.05$ & $78.33 \pm 1.67$ & $73.33 \pm 1.67$ & $61.67^{a} \pm 1.67$ \\
\hline MBPSE,1:4 & $88.33^{b} \pm 1.05$ & $85.00^{\mathrm{b}} \pm 0.00$ & $80.00 \pm 1.29$ & $76.67 \pm 3.33$ & $70.00^{b} \pm 3.16$ \\
\hline MBPSE,1:5 & $82.50^{\mathrm{a}} \pm 1.12$ & $80.83^{a} \pm 0.83$ & $78.33 \pm 1.05$ & $72.50 \pm 1.12$ & $66.67^{\mathrm{ab}} \pm 1.05$ \\
\hline 'F' value & $4.106^{*}$ & $7.308^{* *}$ & $0.535^{\mathrm{NS}}$ & $1.196^{\mathrm{NS}}$ & $3.910^{*}$ \\
\hline BPSE,1:3 & $90.83^{\mathrm{ab}} \pm 0.83$ & $88.33^{\mathrm{ab}} \pm 1.05$ & $85.00^{\mathrm{a}} \pm 0.00$ & $81.67 \pm 1.05$ & $76.67 \pm 1.05$ \\
\hline BPSE,1:4 & $93.33^{b} \pm 1.05$ & $90.00^{\mathrm{b}} \pm 0.00$ & $87.50^{b} \pm 1.12$ & $82.50 \pm 1.71$ & $79.17 \pm 2.01$ \\
\hline BPSE,1:5 & $88.33^{a} \pm 1.05$ & $86.67^{a} \pm 1.05$ & $84.17^{a} \pm 0.83$ & $80.83 \pm 0.83$ & $78.33 \pm 1.05$ \\
\hline 'F' value & $6.502^{* *}$ & $3.750^{\star}$ & $4.839^{*}$ & $0.472^{\mathrm{NS}}$ & $0.819^{N S}$ \\
\hline
\end{tabular}

Means bearing different superscripts in uppercase letter in a row and lowercase letter in a column differ significantly, ${ }^{*} H i g h l y ~ s i g n i f i c a n t ~(P \leq 0.01)$, ${ }^{*}$ ignificant $(P \leq 0.05)$, Ns. Not significant $(P>0.05)$

Table 4: Effect of different semen extenders-dilution ratio and storage periods on motility of lavender guinea fowl spermatozoa at $5^{\circ} \mathrm{C}$ (Mean $\pm \mathrm{SE}$ ).

\section{References}

1. Abdul-Rahman II, Awumbila B, Jeffcoate IA, Robinson JE, Obese FY (2015) Sexing in guinea fowls (Numida meleagris). Poult Sci 94: 311-318

2. Ayorinde $\mathrm{KL}$ (1989) Effect of semen dosage and insemination frequency on the fertility of local pearly Guinea Fowl in Nigeria. Trop Agric 66: 135-136.

3. Konlan SP, Avornyo FK, Karbo N, Sulleyman A (2011) Increasing guinea fow eggs availability and hatchability in the dry season. J World's Poult Res 1: 1-3.

4. Premavalli K (2013) Influence of strain, age and system of management on the productive and reproductive performance of Guinea Fowl. PhD Thesis submitted to the Tamil Nadu Veterinary and Animal Sciences University, Chennai.

5. Aire TA, Ayeni JSO, Olowo-Okorun MO (1983) Some aspects of the reproductive biology of the guinea fowl (Numida meleagris galeata Pallas). The Helmet Guinea Fowl (Numida meleagris galeata Pallas) in Nigeria, Kainji Lake Research Institute, New Bussa, Nigeria, pp: 189-193.

6. Kammerer DM, Moreng RE, Muller HD, Hobbs HW (1972) Turkey semen evaluation for fertility prediction. Poult Sci 51 : 77-82.

7. Wishart GJ, Palmer FH (1986) Correlation of the fertilizing ability of semen from individual male fowls with sperm motility and ATP content. Br Poult Sci 27: $97-102$.

8. Venkatesh G (2005) Effect of pre- Insemination vaginal douching and different semen extenders on fertility and hatchability in turkeys. MVSc Thesis submitted to the Tamil Nadu Veterinary and Animal Sciences University, Chennai.

9. Carter RD, McCartney MG, Chamberlin VD, Wyne JW (1957) The effect of storage time and temperature on fertilizing capacity of Turkey semen. Poult Sci 36: 618-621.
10. Lake PE (1956) A retarding factor in the problem of fowl semen storage. In: Proc. of $3^{\text {rd }}$ International Congress on Animal Reproduction. 3: 104-106.

11. Mohan J, Sharma SK, Kolluri G, Singh RP, Tyagi JS, et al. (2016) Semen quality characteristics and seasonality in different varieties of male Guinea fowl. Adv Anim Vet Sci 4: 320-326.

12. laffaldano N, Rosato MP, Manchisi A, Centoducati G, Meluzzi A (2010) Comparison of different extenders on the quality characteristics of turkey semen during storage. Ital J Anim Sci 4: 513-515.

13. Hudson GH (2015) Fertility Parameters through artificial insemination in Guinea Fowl. M.V.Sc Thesis submitted to the Tamil Nadu Veterinary and Anima Sciences University, Chennai.

14. Burrows WH, Quinn JP (1937) The collection of spermatozoa from the domestic fowl and turkey. Poult Sci 16: 19-24

15. Lake PE, Ravie O (1982) Effect on fertility of storing turkey semen for 24 hours at $10^{\circ} \mathrm{C}$ in fluids of different $\mathrm{pH}$. Br Poult Sci 23: 41-47.

16. Kumararaj R, Omprakash AV (1996) Effect of different diluents, cryoprotectants and equilibration period on freezing of poultry semen. In: Proceedings of $X X$ World Poultry Congress. Delhi, India, pp: 555-568.

17. Sexton TJ, Giesen AF (1982) Beltsville Poultry Semen Extender. 6. Holding turkey semen for $6 \mathrm{hrs}$ at $15^{\circ} \mathrm{C}$. Poult Sci 61 : 1202-1208.

18. Parker JE, McKenzie FF, Kempster HL (1942) Fertility in the male domestic fowl. Research Bulletin 347: 1-50.

19. Snedecor GW, Cochran WG (1994) Statistical methods. IX edition. Oxford and IBH publishing \& Co., Kolkata, India.

20. Mohan J, Sharma SK, Kolluri G, Tyagi JS (2015) Selection of Diluent for Short Term Preservation of Guinea Fowl Semen. Asian J Anim Vet Adv 10: 360-364 
Citation: Keerthy AJ, Omprakash AV, Churchill RR, Hudson GH (2016) Effect of Semen Diluents, Dilution Rates, and Storage Periods on Spermatozoa Motility of Different Varieties of Guinea Fowl. J Vet Sci Technol 7: 378. doi: 10.4172/2157-7579.1000378

Page 6 of 6

21. Lavor CTB, Câmara SR, Bandeira BM, Salgueiro CDM, Castro EV, et al. (2012) Powdered coconut water as preservation medium of guinea fowl (Numida meleagris) sperm. In: Ciência Animal 22: 79-81.

22. Słowińska M, Liszewska E, Dietrich GJ, Ciereszko A (2012) Characterization of proacrosin/acrosin system after liquid storage and cryopreservation of turkey semen (Meleagris gallopavo). Theriogenology 78: 1065-1077.

23. Mohan J, Khanday JM, Singh RP, Tyagi JS (2013) Effect of Storage on the
Physico-Biochemical Characteristics and Fertility of Guinea Fowl Semen. Adv Anim Vet Sci 1: 65-68.

24. Clark RN, Bakest MR, Ottinger MA (1984) Morphological changes in Chicken and Turkey spermatozoa incubated under various conditions. Poult Sci 63 801-805.

25. Saeki Y (1960) Crooked-Necked Spermatozoa in Relation to Low Fertility in the Artificial Insemination of Fowl. Poult Sci 39: 1354-1360. 